\title{
Nitrogen Critical Loads for Natural and Semi-Natural Ecosystems: The Empirical Approach
}

Article in Water Air and Soil Pollution · December 1995

DOI: 10.1007/BF01186195

CITATIONS

150

2 authors:

Roland Bobbink

B-WARE Research Centre

227 PUBLICATIONS 9,065 CITATIONS

SEE PROFILE
READS

150

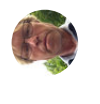

Jan G M Roelofs

Radboud University

313 PUBLICATIONS $\quad 10,777$ CITATIONS

SEE PROFILE

Some of the authors of this publication are also working on these related projects:

Project Rock dust as a means to counteract soil acidification - Dutch research initiatives View project

Project PhD project seagrass under nutrient loads, hydrodynamics and turtle grazing View project 


\title{
NITROGEN CRITICAL LOADS FOR NATURAL AND SEMI-NATURAL ECOSYSTEMS: THE EMPIRICAL APPROACH
}

\author{
ROLAND BOBBINK and JAN G.M. ROELOFS \\ Department of Ecology, Researchgroup Environmental Biology \\ University of Nijmegen, Toernooiveld 1, 6525 ED Nijmegen The Netherlands
}

\begin{abstract}
One of the major threats to the structure and the functioning of natural and semi-natural ecosystems is the recent increase in air-borne nitrogen pollution $\left(\mathrm{NH}_{\mathrm{y}}\right.$ and $\left.\mathrm{NO}_{\mathrm{x}}\right)$. Ecological effects of increased $\mathrm{N}$ supply are reviewed with respect to changes in vegetation and fauna in terrestrial and aquatic natural and semi-natural ecosystems. Observed and validated changes using data of field surveys, experimental studies or, of dynamic ecosystem models (the 'empirical approach'), are used as an indication for the impacts of $\mathrm{N}$ deposition. Based upon these data $\mathrm{N}$ critical loads are set with an indication of the reliability. Critical loads are given within a range per ecosystem, because of spatial differences in ecosystems. The following groups of ecosystems have been treated: softwater lakes, wetlands \& bogs, species-rich grasslands, heathlands and forests. In this paper the effects of $\mathrm{N}$ deposition on softwater lakes have been discussed in detail and a summary of the $\mathrm{N}$ critical loads for all groups of ecosystems is presented. The nitrogen critical load for the most sensitive ecosystems (softwater lakes, ombrotrophic bogs) is between $5-10 \mathrm{~kg} \mathrm{~N} \mathrm{ha}^{-1} \mathrm{yr}^{-1}$, whereas a more average value for the range of studied ecosystems is $15-20 \mathrm{~kg} \mathrm{~N} \mathrm{ha}^{-1} \mathrm{yr}^{-1}$. Finally, major gaps in knowledge with respect to $\mathrm{N}$ critical loads are identified.
\end{abstract}

\section{Introduction}

Mans activities pose a number of threats to the structure and the function of natural and semi-natural ecosystems, and thus to the natural variety of plant and animal species. One of the major threats is the increase in air-borne $\mathrm{N}$ pollution $\left(\mathrm{NH}_{\mathrm{y}}\right.$ and $\left.\mathrm{NO}_{\mathrm{x}}\right)$ in recent decades. Nitrogen is the limiting nutrient for plant growth in many of the natural and semi-natural ecosystems and most of the plant species from these habitats are adapted to nutrient-poor conditions, and can only compete successfully on soils with low $\mathrm{N}$ levels (e.g. Chapin, 1980; Tamm, 1991). Nitrogen is, furthermore, the only nutrient of which the cycling through the ecosystem is almost exclusively regulated by biological processes. To establish reliable critical loads for $\mathrm{N}$, it is essential to understand the effects of $\mathrm{N}$ upon these ecosystem processes. The most important impacts of increased atmospheric $\mathbf{N}$ deposition upon biological systems are: (i) short-term effects of $\mathrm{N}$ gases and aerosols to individual species (critical levels); (ii) soil-mediated effects of acidification; (iii) soil-mediated effects of $\mathrm{N}$ enrichment; (iiii) increased susceptibility to secondary stress factors and, (iiiii) changes in (competitive) relationships between species, resulting in loss of diversity.

Empirical critical loads for $\mathrm{N}$ deposition to natural and semi-natural ecosystems have been discussed and established at the 1992 UN/ECE workshop at Lökeberg (Sweden; Grennfelt and Thörnelöf, 1992) and updated in 1994 at Grange-over-Sands (UK; (Hornung et al., 1995) using the working definition adopted at Lökeberg. These $\mathrm{N}$ critical loads will be incorporated in near future in the WHO Air Quality Guidelines for 
Europe (WHO, 1996) and used in the negotiations for a new $\mathrm{NO}_{\mathrm{x}}$ protocol.

The critical $\mathrm{N}$ loads have been set on the basis of observed and published changes in the structure or function of ecosystems using experimental data, field observations and/or dynamic ecosystem models (the 'empirical approach') (Bobbink et al., 1992; Bobbink and Roelofs, 1995). Changes in plant development and in species composition or dominance have been used as an 'detectable change' for the impacts of excess $\mathrm{N}$ deposition, but in some cases a change in ecosystem function, such as $\mathrm{N}$ leaching or $\mathrm{N}$ accumulation has been used (e.g. ombrotrophic bogs; coniferous forests). The $\mathrm{N}$ critical loads have been established within a range per ecosystem, because of (i) real intra-ecosystem variation, (ii) intervals between experimental treatments, and (iii) uncertainties in deposition values. Furthermore, the reliability of the presented figures is indicated:

- reliable: when a number of published papers of various studies show comparable results;

- quite reliable: when the results of some studies are comparable;

- best guess: when no data are available for this type of ecosystem. The $\mathrm{N}$ critical load is then based upon knowledge of ecosystems which are likely to be more or less comparable with this ecosystem.

The $\mathrm{N}$ critical loads clearly depend on (i) the abiotic conditions, especially those which influence the nitrification potential and immobilization rate in the soil, and (ii) the land use and management in the past and present. Therefore, the empirical $\mathrm{N}$ critical loads have been evaluated for specific groups of related ecosystems. The following groups of semi-natural and natural ecosystems have been treated: softwater lakes, wetlands \& bogs, species-rich grasslands, heathlands and forests. In this paper the $\mathbf{N}$ critical loads for European soft-water lakes are discussed in detail, whereas the $\mathrm{N}$ critical loads for the other ecosystems are summarized. Finally major gaps in knowledge and recommendations with respect to empirical nitrogen critical loads are identified.

\section{Effects of $\mathbf{N}$ deposition on softwater lakes}

In the lowlands of Western Europe many soft waters are found on sandy soils which are poor in calcium carbonate or almost devoid of it. The waters are poorly buffered and the concentrations of calcium in the water layer are very low; they are shallow and fully mixed water bodies, with periodically fluctuating water levels, and are mainly fed by rain water, and thus oligotrophic. These softwater ecosystems are characterized by plant communities from the phytosociological alliance LITTORELLION (Schoof-van Pelt, 1973; Wittig, 1982; Roelofs, 1986; Vöge, 1988; Arts, 1990). The stands of these communities are characterized by the presence of rare and endangered isoetids, such as Littorella uniflora, Lobelia dortmanna, Isoetes lacustris, I. echinospora, Echinodorus species, Luronium natans and many other softwater macrophytes. For more details on these communities see Schoof-van Pelt (1973) and Schaminée et al. (1992). These soft waters are nowadays almost all within nature reserves and have become very rare in Western Europe. This decline may be illustrated by the fact that Littorella uniflora was known from more than 230 sites in the Netherlands in the early 1950s, of which only about 40 still exist. Furthermore, a strong decline in amphibians has been observed in 
these soft waters (Leuven et al., 1986).

The effects of nitrogen pollutants on these soft waters have been intensively studied in the Netherlands both in field surveys and experimental studies. Field observations in about 70 soft waters (with well-developed isoetid vegetation in the $1950 \mathrm{~s}$ ) showed that the waters in which these macrophytes were still abundant in the early 1980 s, were poorly buffered (alkalinity is 50 to $500 \mu \mathrm{eq} \mathrm{I}^{-1}$ ), circumneutral ( $\mathrm{pH}=5$ 6) and very low in dissolved nitrogen (Roelofs, 1983; Arts et al., 1990). The softwater sites where these plant species had disappeared, could be divided into two groups. In 12 of the 53 softwater sites eutrophication, resulting from inflow of enriched water, seemed to be the cause of the decline. In this group of non-acidified waters plant species such as Lemna minor had become dominant, with high concentrations of phosphate and ammonium in the sediments. In some water bodies a dense plankton bloom was observed.

In the second group of lakes and pools (41 out of 53) another development had taken place: the isoetid species were replaced by dense stands of Juncus bulbosus or aquatic mosses such as Sphagnum cuspidatum or Drepanocladus fluitans. This clearly indicates acidification of these soft waters in recent decades, probably caused by enhanced atmospheric deposition. In the same field study, it has been shown that the nitrogen levels of the water layer were higher in ecosystems where the natural vegetation had disappeared, compared with ecosystems where the LITTORELLION stands were still present (Roelofs, 1983). This strongly suggests the detrimental effects of atmospheric nitrogen deposition in these softwater lakes.

A number of ecophysiological studies has revealed the importance of (i) inorganic carbon status of the water as a result of intermediate levels of alkalinity, and, (ii) low nitrogen concentrations, for the growth of the endangered isoetid macrophytes. Furthermore, almost all of the typical softwater plants had a relatively low potential growth rate. Increased acidity and higher concentrations of ammonium in the water layer clearly stimulated the development of Juncus bulbosus and submerged mosses such as Sphagnum and Drepanocladus species (Roelofs et al., 1984; Den Hartog, 1986). It has also been shown in cultivation experiments that the nitrogen species involved (ammonium or nitrate) differentially influenced the growth of the studied species of water plants. Almost all of the characteristic softwater isoetids developed better with nitrate instead of ammonium addition, whereas Juncus bulbosus and aquatic mosses (Sphagnum \& Drepanocladus), were clearly stimulated by ammonium nutrition (Schuurkes et al., 1986). The importance of ammonium for the growth of these aquatic mosses is also reported by Glime (1992).

The effects of atmospheric deposition have been studied in small-scale softwater systems during a 2-year treatment with different artificial rainwaters. Acidification, without airborne nitrogen input (sulphuric acid), has not resulted in a mass growth of Juncus bulbosus and a diverse isoetid vegetation remains present. However, after increasing the nitrogen concentration in the precipitation (as ammonium sulphate), similar changes in floristic composition as under field conditions have been observed: a dramatic increase in dominance of Juncus bulbosus, of submerged aquatic mosses and of Agrostis canina (Schuurkes et al., 1987). It became obvious that the observed changes occurred because 
of the effects of ammonium sulphate deposition, leading to both eutrophication and acidification. The increased levels of ammonium in the system stimulated directly the growth of plants such as Juncus bulbosus, whereas the surplus of the extra ammonium will be nitrified in these waters $(\mathrm{pH} \geq 4.0)$. During this nitrification process $\mathrm{H}^{+}$-ions are produced, which increase the acidity of the system. The results of this study demonstrate that the changes in composition of the vegetation have occurred after 2-year treatment with $\geq 19 \mathrm{~kg} \mathrm{~N} \mathrm{ha}^{-1} \mathrm{yr}^{-1}$. A reliable critical load for nitrogen deposition in these shallow softwater lakes is thus most likely below $19 \mathrm{~kg} \mathrm{~N} \mathrm{ha}^{-1} \mathrm{yr}^{-1}$, and most probably between 5 and $10 \mathrm{~kg} \mathrm{~N} \mathrm{ha}^{-1} \mathrm{yr}^{-1}$ (Table 1). This value is supported by the observation that the strongest decline in the species composition of the Dutch LITTORELLION communities has coincided with nitrogen loads of 10 to $13 \mathrm{~kg} \mathrm{~N} \mathrm{ha}^{-1} \mathrm{yr}^{-1}$ (Arts, 1990).

\section{Conclusions and Gaps in Knowledge}

In this paper the effects of $\mathrm{N}$ deposition on softwater ecosystems have been evaluated in detail with published evidence and a $\mathrm{N}$ critical load for these sensitive systems are presented. Based upon observed changes in structure and function of natural and seminatural ecosystems and, sometimes with the use of dynamic ecosystem models, $\mathrm{N}$ critical loads have been formulated and set for all treated systems (Table 1). Most of earths biodiversity is present in semi-natural and natural ecosystems and nowadays many anthropogenous stress factors threaten this natural heritage. One of these threats is the air-borne $\mathrm{N}$ pollution $\left(\mathrm{NH}_{\mathrm{x}}\right.$ and $\mathrm{NO}_{\mathrm{y}}$ ). It is crucial to control the $\mathrm{N}$ load, in order to prevent negative effects on these ecosystems. In this document critical loads for $\mathrm{N}$ are given as reliable as possible. As most of the research efforts have focused on acidification in forest systems, serious gaps in knowledge exist on the effects of enhanced $\mathrm{N}$ deposition on natural and semi-natural terrestrial and aquatic ecosystems. The following gaps in knowledge are important:

- quantified effects of enhanced $\mathrm{N}$ deposition on fauna in all reviewed ecosystems are extremely scarce;

- the critical load for $\mathrm{N}$ deposition to arctic/(sub)alpine systems is largely speculative;

- more research is needed on the $\mathrm{N}$ effects on the forest floor, because most of the research had focused on the trees only.

- a serious gap in knowledge is the effect of $\mathrm{N}$ on forests on calcareous bedrock, which are not sensitive to acidification;

- more long-term research is needed, especially in montane/subalpine meadows, speciesrich grasslands, ombrotrophic bogs and (sensitive) freshwater ecosystems;

- the long-term effects of enhanced atmospheric $\mathrm{N}$ in grassland and heathland of high nature conservation importance under different management regimes are insufficiently known.

- long-term effects of nitrogen eutrophication in (sensitive) aquatic ecosystems (freshwater and marine) need further research;

- the possible differential effects of the deposited $\mathrm{N}$ species $\left(\mathrm{NO}_{\mathrm{y}}\right.$ or $\left.\mathrm{NH}_{\mathrm{x}}\right)$ are insufficiently known to make a differentation between these $\mathrm{N}$ species for critical load establishment. 
To establish reliable critical loads, it is crucial to understand the long-term effects of increased $\mathrm{N}$ deposition on ecosystem processes in a representative range of communities. It is thus very important to quantify the effects of $\mathrm{N}$ loads on natural and semi-natural terrestrial and "freshwater ecosystems by manipulation of $\mathrm{N}$ inputs in long-term ecosystem studies in unaffected and affected areas. These data are essential to validate the presented critical loads and to develop robust dynamic ecosystem models, which are reliable enough to calculate critical loads for $\mathrm{N}$ deposition in semi-natural and natural ecosystems.

\section{TABEL I}

Summary of the empirical $\mathrm{N}$ critical loads $\left(\mathrm{kg} \mathrm{N} \mathrm{ha}^{-1} \mathrm{yr}^{-1}\right)$ to (semi-)natural freshwater and terrestrial ecosystems. \#\# reliable; \# quite reliable and (\#) best guess (after Bobbink et al,. 1992; Bobbink and Roelofs, 1995).

\begin{tabular}{|c|c|c|}
\hline & Critical load & Indication \\
\hline Shallow softwater lakes & $5-10 \# \#$ & Decline isoetid species \\
\hline Mesotrophic fens & 20-35 \# & Increase tall graminoids, decl. diversity \\
\hline Ombrotrophic (raised) bogs & $5-10 \#$ & $\begin{array}{l}\text { Decrease Sphagnum and subordinate species, } \\
\text { increase tall graminoids; } \mathrm{N} \text { accumulation }\end{array}$ \\
\hline Calcareous species-rich grassland & $14-25 \# \#$ & Increase tall grass, decline diversity \\
\hline Neutral-acid species-rich grassland & $20-30 \#$ & Increase tall grass, decline diversity \\
\hline Montane-subalpine grassland & $10-15(\#)$ & Increase tall graminoids, decl. diversity \\
\hline Lowland dry-heathland & $15-20$ \#\# & Transition heather to grass \\
\hline Lowland wet-heathland & $17-22 \# \#$ & Transition heather to grass \\
\hline Species-rich heaths/acid grassl. & $7-15 \#$ & Decline sensitive species \\
\hline Upland Calluna moorland & $10-20(\#)$ & Decrease heather \\
\hline Arctic and alpine heaths & $5-15(\#)$ & $\begin{array}{l}\text { Decline lichens, mosses and evergreen dwarf- } \\
\text { shrubs, increase in grasses and herbs }\end{array}$ \\
\hline Coniferous forest (acidic, managed) & $10-20 \# \#$ & Changes ground flora; $N$ leaching \\
\hline Deciduous forest (acidic managed) & $15-20 \#$ & Changes ground flora \\
\hline Deciduous forests (calcareous) & $15-20(\#)$ & Changes ground flora \\
\hline Coniferous tree health & $10-15 \#$ & $\begin{array}{l}\text { Nutrient imbalance, low nitrif. (Boxman et } \\
\text { al., 1988) }\end{array}$ \\
\hline Coniferous tree health & $20->50 \#$ & $\begin{array}{l}\text { Nutrient imbalance, intermed/high nitrif. } \\
\text { (Boxman et al., 1988) }\end{array}$ \\
\hline Deciduous tree health & $15-20 \#$ & Nutrient imbalance; shoot-root ratio \\
\hline
\end{tabular}

\section{References}

Arts, G.H.P.: 1990. Deterioration of atlantic soft-water systems and their flora, a historical account. PhD thesis, University of Nijmegen. 
Arts, G.H.P., Van Der Velde, G., Roelofs, J.G.M. and Van Swaay, C.A.M.: 1990. Freshwater Biol. 24, 287294.

Bobbink, R., Boxman, D., Fremstad, E., Heil, G., Houdijk, A. and Roclofs, J.: 1992. In: Critical loads for Nitrogen. Nord (Miljörapport) 41, 111-159.

Bobbink, R. and Roelofs, J.G.M.: 1995. In: Mappjng and modelling of critical loads for nitrogen - a workshop report. Institute of Terrestrial Eoclogy, Peniciuik , 9-19.

Boxman, D., Van Dijk, H., Houdijk, A. and Roelofs, J.: 1988. In: Critical loads for sulphur and nitrogen. Miljörapport 15, 295-323.

Chapin, F.S.: 1980. Ann. Rev. Ecol. Syst. 11: 233-260.

Den Hartog, C.: 1986. In: Proceedings 1st. Internat. Symposium on water milfoil (Myriophyllum spicatum) and related Haloragaceae species. Vancouver, Canada, pp. 51-58.

Glime, J.M.: 1992. In: Bryophytes and lichens in a changing environment. Clarendon Press, Oxford, pp. 333361.

Grennfelt, P. and Thörnelöf, E. (eds.): 1992. Critical loads for nitrogen. Nord (Miljörapport) 41, 428 pp.

Hornung, M., Sutton, M.A. and Wilson, R.B.: 1995. Mapping and modelling of critical loads for nitrogen - a workshop report. Institute of Terrestrial Eoclogy, Peniciuik, 207 pp.

Leuven, R.S.E.W,, Den Hartog, C, Christiaans and Heyligers, W.H.C.: 1986. Experientia 42: 495-503.

Roelofs, J.G.M.: 1983. Aquat. Bot. 17: 139-155.

Roelofs, J.G.M.: 1986. Experientia 42: 372-377.

Roelofs, J.G.M., Schuurkens, J.A.A.R. and Smits, A.J.M.: 1984. Aquat. Bot. 18: 389-411.

Schaminée, J.H.J., Westhoff, V. and Arts, G.H.P.: 1992. Phytocoenologia 20: 529-558.

Schoof-van Pelt, M.M.: 1973. Littorelletea, a study of the vegetation of some amphiphytic communities of western Europe. Ph.D. Thesis, University of Nijmegen.

Schuurkens, J.A.A.R., Kok, C.J. and Den Hartog, C.: 1986. Aquat. Bot. 24: 131-146.

Schuurkes, J.A.A.R. Elbers, M.A., Gudden, J.J.F. and Roelofs, J.G.M.: 1987. Aquat. Bot. 28: 199-225.

Tamm, C.O.: 1991. Nitrogen in terrestrial ecosystems. Questions of productivity, vegetational changes, and ecosystem stability. Springer Verlag, Berlin.

Vöge, M.: 1988. Limnologica (Berlin) 19: 89-107.

World Health Organisation (WHO): 1996. Air quality guidelines for Europe. WHO, Geneva, pp xxx.

Wittig, R.: 1982. Decheniana (Bonn) 135: 14-21 